JOYCE, James. Dublinenses. Tradução de Caetano W. Galindo. São Paulo, Companhia das Letras, 2018. 280p.

ISBN 9788582850770

RUfFATTO, Luiz. A cidade dorme. São Paulo: Companhia das Letras, 2018. 128 p. ISBN 9788535926644

\title{
DOIS MENINOS E A PARALISIA: OS CONTOS DE ABERTURA DO NOVO LIVRO DE LUIZ RUFFATO E DUBLINENSES, EM NOVA TRADUÇÃO
}

\section{PARALYSIS AND TWO BOYS: THE OPENING SHORT STORIES IN LUIZ RUFFATO'S NEW BOOK, AND DUBLINERS IN A NEW TRANSLATION}

Israel Augusto Moraes de Castro Fritsch ${ }^{1}$

Dublinenses é, sabidamente, a coleção de 15 contos escritos pelo irlandês James Joyce, sobre habitantes de sua cidade natal. O livro é o retrato da sociedade daquela época e sua perdição, um estado de espírito de inferioridade em relação à Inglaterra e ao continente europeu; centraliza a maior parte das histórias entre as classes baixa e média e seus personagens, muitos, próximos da pobreza, têm a vida marcada por outras contendas morais: casamentos falidos, alcoolismo, opressão católica, alpinismo social, melancolia e paralisia. É possível ler cada um dos textos a partir desta paralisia e de como os personagens reagem a ela, muitas vezes, atraídos para e pela morte.

O clássico irlandês agora ganha mais uma tradução em Português, a terceira disponível no mercado $^{2}$, escrita por Caetano W. Galindo para a coleção Penguin Classics Companhia das Letras. Ele especializou-se em Joyce e já havia encarado a obra-prima Ulysses (Penguin Classics Companhia das Letras), a partir da qual escreveu Sim, Eu Digo Sim: Uma Visita Guiada ao Ulysses de James Joyce, lançada pelo mesmo selo. Portanto, esta edição nasce com o peso de ter sido traduzida por uma autoridade em Joyce e, por isso, vem com muitas notas de rodapé, contextualizando a Irlanda da época.

\footnotetext{
${ }^{1}$ Jornalista e mestrando em Estudos de Literatura do Programa de Pós-graduação em Letras da Universidade Federal do Rio Grande do Sul.

${ }^{2}$ As demais são da edições BestBolso, com tradução de Hamilton Trevisan, e L\&PM, com tradução de Guilherme da Silva Braga.
} 
A Cidade Dorme é uma coleção de 20 contos escritos pelo brasileiro Luiz Ruffato sobre, principalmente, os habitantes das periferias brasileiras, que tratam da espontaneidade, da simplicidade e de uma certa esperança da classe média baixa em constante transformação; gente que poderia se entregar às peripécias do destino, mas que "a vergonha empurra pra frente" como diz um dos personagens - , não tão facilmente.

Aproximar as duas coletâneas é sintetizar o Zeitgeist de uma certa estratificação social em países em desenvolvimento, de acordo com a época de cada livro: Dublinenses, na virada do século XX, e A Cidade Dorme, entre as décadas de 1960 e 1970. Os dois contos de abertura de cada obra, que tratam da infância e foram escritos em primeira pessoa, mostram a voz de um garoto perante uma mudança significativa em sua realidade: a morte e a mudança de casa e expectativa de vida, respectivamente. À medida que os meninos contam suas descobertas, expõem suas realidades do ponto de vista de quem está, ainda, assimilando o mundo.

Uma das possíveis leituras de Dublinenses é classificar os contos em relação às faixas etárias da vida. E o livro começa com três textos sobre a infância. São contos em que o narrador aciona uma memória viva ou mesmo vive o momento sem exata precisão do ponto de onde ele narra. $\mathrm{O}$ texto remete à compreensão de mundo pela criança e à dimensão da infância, o que possibilita que a escrita enfoque o processo imediato das descobertas.

“As Irmãs" trata de um garoto que se depara com a morte; o desaparecimento de um amigo, o padre James Flynn (de prenome igual ao do autor), que, vítima de derrames constantes, morria aos poucos diante do menino. Aos olhos do garoto, seu amigo representa uma fragilidade desconcertante - o corpo do homem perece, denotando, também, a falência da Igreja Católica, em uma possível leitura que não aprofundaremos aqui. Já a fragilidade da criança é o fato de viver com os tios: não sabemos de sua vida pregressa. Isto já a coloca em uma situação de vulnerabilidade - como a doença que paralisa e mata o padre aos 65 anos. Diante da morte do amigo, o menino enfrenta a paralisia e vai assimilando a morte em cenários de luz e sombra ao longo da narrativa.

A presença da noite e as paisagens escuras prevalecem em contraponto à luz solar. Já no começo da história, o menino recorda que passava pela casa do padre "noites a fio", e "toda noite", diante da imagem do amigo em processo de desaparecimento, falava a si mesmo a palavra "paralisia", que the soava estranha e, diante da morte do homem, passou a significar "algum ser malévolo e pecaminoso". De certa forma, o menino enquadra o padre, que representa a igreja e a moral claudicantes (o padre fora desligado da igreja e havia desconfianças para com ele) a uma amizade que também era uma ameaça. 
Ao encarar "noites a fio" o velho amigo perecer, espiando através da luz que escoava pelas frestas da janela da casa do homem, cercada pelo breu, o menino vê-se em um espelho: a realidade do padre é a realidade de todo um país paralisado. (É possível, além da relação mais superficial com a morte e com a própria igreja, como já referi, associar a paralisia à condição da Irlanda em relação ao mundo, algo que aparece nos demais contos, de como a sociedade estratificada daquela virada de século está paralisada quanto às possibilidades de mudança social e mesmo da chegada de um certo progresso capitalista no que concerne ao restante da Europa).

Perante o mistério da morte, o menino caminha ao encontro da luz - e da razão. Em determinado momento da história, perto da casa do homem, naquele momento já defunto, em vez de entrar para ver o morto, ele tenta desviar da realização da morte, atravessando para "o lado da rua que estava no sol”, como se esta fosse uma alternativa metafísica. Quando está ao sol, ele atinge outro grau de constatação e ressignifica a presença do padre em sua vida: sentese livre com morte do amigo.

O texto é bastante reticente quanto à profundidade da amizade entre eles. Em algum momento, depois da morte do amigo-padre, um conhecido da família, Sr. Cotter, sugere que uma criança deva brincar com outras, "para aprender a se defender", como concorda o tio do garoto, e não conviver com um velho padre. Ao estabelecer um lugar para a infância, isto é, brincar com outras crianças, tem-se aqui já a ideia de proteção para as agruras do mundo ou do espaço da fantasia que deve preencher o tempo dos meninos e meninas nessa idade, porque, no mais, a vida é dura. A vida também é cheia de reticências, e o garoto percebe isso. Que mistério teria o padre cuja morte o aliviava?

Enquanto na caminhada pelo sol, o menino também compreende um sonho que tivera recentemente - como se estivesse em um país "com costumes estranhos" e mais oriental, que é também a estranheza e a realização de viver em uma Irlanda que ele mesmo não compreende e que lhe parecia "bem longe" - agora, nem tanto. O fato de não lembrar como o sonho acabava sugere que ele vive este sonho acordado: tudo lhe é estranho. A morte do padre implica atravessar para o lado do sol e procurar um entendimento de sua realidade obscura em um sonho ainda em processo, que é a própria vida em um país a ser descoberto, como se fosse a misteriosa e onírica Pérsia que o assombra.

A criança depara-se com o corpo durante o velório, enfim encarado, ao qual a tia a conduz quando o sol se põe. É a volta da noite à narrativa. O narrador frisa esta condição, já que a razão solar que dá consciência à vida dá lugar ao mistério mais uma vez. A constatação mais intensa da existência da morte vem de uma frase curta e definitiva do narrador: "Ele estava 
no caixão", uma das poucas sentenças com esta concisão e que remete ao irremediável - à paralisia que ronda o conto, agora, definitiva. E ele alerta: ali, já não pensa com clareza. É a luz que se resguarda no horizonte.

Então, o menino ouve uma conversa entre sua tia e as irmãs que cuidavam do falecido; elas tratam da decepção do homem, da vez em que ele sumiu e o surpreenderam com meio sorriso, acocorado num canto escuro do confessionário, o ponto mais íntimo e reflexivo da capela. A morte já o rondava; algo havia quebrado, como o cálice que o padre quebrou, alegadamente culpa de um coroinha, fato que reverberou na comunidade e que poderia servir de metáfora para uma leitura da pedofilia ou de um comportamento pouco religioso do padre, o que não é esclarecido no conto. De qualquer forma, a desilusão precede a morte. Daí o alívio do menino, à procura pela luz, do outro lado da rua, na emergência de um novo amanhecer.

Quase um século depois, no Brasil, um outro menino abre a narrativa de um livro de contos. O título do livro, A Cidade Dorme, já antecipa certa inocência, emana imagens de recolhimento e silêncio e, mesmo como a Irlanda de Joyce, a paralisia da noite. Ao mesmo tempo, anuncia a expectativa de um novo dia, uma aurora social.

O primeiro conto, cujo nome "Minha Vida" lembra as composições dos primeiros anos de escola (como "Minha família", "Minhas férias" etc.), é o relato de um menino sobre a mudança da família do centro da cidade, marginalizado, e do casebre alugado no cortiço, para a casa própria no bairro distante, sem infraestrutura, nos idos dos anos de 1960, quando a periferia equivalia a sossego, dignidade e recomeço para muitas famílias, antes que se transformasse no espaço de desalento, exclusão e violência que é hoje.

A família vai morar no Paraíso - nome do bairro distante. Para a irmã da criança, feio e longe. Apesar da mudança de residência já ter sido feita há um ano, quando é narrada pelo garoto, a casa ainda não está pronta, porque "falta emboçar as paredes de fora e pintar as de dentro". Quer dizer que a vida para aquela gente ainda está em processo de mudança, e o país ainda não está pronto: apesar o milagre econômico proveniente do Regime Militar e da ampliação do acesso à moradia, como lhes acontece, há algo inacabado no Brasil.

O rapazote de pai pipoqueiro e mãe lavadeira, como foram os pais do autor, anuncia que o pai o quer torneiro-mecânico para o futuro, a trabalhar nas prósperas fábricas de automóveis da Grande São Paulo, expectativa profissional limite para gente pobre e iletrada e que também foi o pontapé inicial do autor de formação operária, no que pese o teor autobiográfico desta história de abertura.

A emergência do lugar de fala não é novidade na obra de Ruffato, mas irrompe com toda a força, dando voz autêntica à essa horda de trabalhadores, batalhadores, gente que dói, as 
pessoas invisíveis - eternizadas pelo quadrinista americano e judeu Will Eisner; gente do aperto: cama apertada, casa apertada, ônibus apertado, dinheiro apertado.

Em 1970, a população urbana ultrapassava a rural, revelando uma mudança no cenário econômico de expectativa de progresso e possibilidades - cujo preço pagamos ainda hoje. Preocupada com a sobrevivência, a família nem sequer se dá conta da condição de opressão pela qual passava o Brasil. Para esses pobres com rumo incerto, o milagre econômico era uma chance de prosperar nas fábricas de carro, “onde está o futuro", segundo o pai do menino. Neste sentido, "Minha Vida" é muito mais inocente que "As Irmãs". O narrador-criança de Ruffato é a criança que brinca na rua e com os animais. Contudo, em ambos os casos, a narrativa do ponto de vista do olhar da criança pontua a realidade em que sobrevivem, com o dito e, muito mais, o não-dito ou entreouvido: de um lado, a paralisia, a morte e o jogo de luzes que afligem o menino joyceano; de outro, o sacolejar da mudança rumo à descentralização da vida em uma realidade inacabada do brasileiro médio. Aqui, a falta de noção social se dá justamente pela distância que a família toma da realidade, rumo à periferia, na expectativa de que as paredes recebam, algum dia, o acabamento esperado, com o dinheiro do progresso das fábricas de carro. Lá, o cálice irreversivelmente quebrado e o velho padre morto anunciavam o fim da infância e a idade da razão. Assim começam os livros de contos que aprofundam países distantes no tempo e no espaço, mas tão similares no tocante às gentes de pouca voz. 